\title{
RANCANG BANGUN APLIKASI PEREKRUTAN PEGAWAI BERBASIS WEB (STUDI KASUS UNIVERSITAS UNIVERSAL)
}

\author{
Marfuah $^{1}$ dan Suryo Widiantoro ${ }^{2}$ \\ ${ }^{1,2)}$ Program Studi Sistem Informasi Universitas Universal \\ Kompleks Maha Vihara Duta Maitreya, Sungai Panas, Batam 29456, Kepulauan \\ Riau - Indonesia \\ Email: marfuah@uvers.ac.id, suryo.widiantoro@uvers.ac.id
}

\begin{abstract}
Recruitment competition continues to increase because of the high needs for life and the limited needs of work of an organization. There are many enthusiasts who need jobs from various fields of science ranging from work in accordance with their field to cultivate jobs outside their field. The recruitment aspect begins to get special attention, as it can hinder the rate of development of the organization.

The organizations needs skilled employer to bring significant leads. Theyhave to develop recruitment strategies and expand the reach of advertising. E-recruitment has several stages that are determined by the organization, using internet media such as WEB to get a decent workforce effectively and efficiently.

The application design or conceptual system starting from problem identification, system requirement analysis to design, depiction using a model of Unified Modeling Language as a communication bridge tosome aspects of system, simplify the system development as needed. The design of the application contains the actual process in the recruitment process.
\end{abstract}

Keyword: Design, E-Recruitment, Recruitment, WEB.

PENDAHULUAN

Aspek perekrutan mulai mendapatkan perhatian khusus, karena proses perekrutan yang tidak sesuai dengan kebutuhan. Hal ini dapat menghambat laju perkembangan dalam suatu organisasi. Evolusi peradaban manusia bertransformasi dan membutuhkan tenaga kerja terampil yang dapat membawa organisasi kearah lebih baik yang terjadi secara signifikan (Irsan dkk, 2014). Kebutuhan hidup yang terus meningkat dan terbatasnya kebutuhan perkerjaan pada suatu organisasi maka terciptalah dunia persaingan. Bersaing dengan kemampuan secara sehat membutuhkan kepribadian yang baik. Dari berbagai bidang ilmu ada banyak peminat yang membutuhkan perkerjaan, mulai dari perkerjaan yang sesuai dengan bidangnya hingga menggeluti pekerjaan yang tidak sesuai dengan bidangnya.

Adanya daya saing yang meningkat dalam bidang perekrutan, maka organisasi harus mengembangkan 
strategi perekrutan dan memperluas jangkauan periklanan (Sharma, 2014).

Hasil survei menunjukkan lebih dari 50 organisasi menggunakan $e$ recruitment. Penyebab organisasi bertransformasi dari metode perekrutan tradisional ke e-recruitment diantaranya, citra organisasi menjadi meningkat dengan adanya kehadiran WEB dan penggunaan internet, biaya perekrutan lebih rendah, mengurangi biaya kerja dan beban administrasi, kemampuan untuk menyebarluaskan informasi (Ramaabaanu, 2014). Dampak yang nyata mampu ditimbulkan oleh E-recruitment terhadap proses perekrutan secara menyeluruh, dengan terjadinya perubahan terhadap urutan, pembagian tugas dan pengerjaan sejumlah tugas yang berulang (Holm, 2010)

Penelitian sebelumnya dalam mengembangkan aplikasi e-recruitment untuk perekrutan karyawan menggunakan metode Research \& Development dan dalam perancangan aplikasi e-recruitment menggunakan Software Development Life Cycle dengan pendekatan Waterfall (Gat dan Kosasi., 2014).

Pembuatan rancang bangun aplikasi perekrutan pegawai berbasis
WEB bertujuan untuk mengubah proses perekrutan dalam organisasi Universitas Universal. Menciptakan kemudahan terjalinnya hubungan antara calon pegawai dan bagian kepagawaian. Menjangkau calon pegawai potensial secara lebih luas dan untuk mempercepat terisisnya lowongan pekerjaan.

\section{KERANGKA TEORI}

1. Sistem Informasi Sumber Daya Manusia

Sistem informasi sumber daya manusia merupakan sistem yang mendukung segala proses di bidang manajemen sumber daya manusia seperti perekrutan, seleksi, pemberian pekerjaan, pengembangan, pelatihan, serta penilaian kinerja pada suatu organisasi (Ayu dan Perdana., 2014).

Sistem perekrutan termasuk dalam sistem informasi sumber daya manusia relasional, untuk membantu proses manajemen sumber daya manusia yang lebih kompleks, yang berkaitan dengan rekrutmen dan seleksi, pelatihan dan pengembangan, dan kinerja karyawan (Ayu dan Perdana., 2014). 
2. Perekrutan

Perekrutan merupakan suatu proses menganalisis persyaratan pekerjaan, mencari dan mengumpulkan calon atau kandidat yang memenuhi syarat dan mempekerjakan calon atau kandidat yang sesuai dengan kebutuhan (Sills., 2014).

Proses yang saling terkait dengan perekrutan adalah seleksi. Seleksi merupakan proses memilih calon atau kandidat yang terbaik atau layak untuk suatu pekerjaan dari sekian banyak kandidat yang telah dikumpulkan (Sills., 2014).

\section{E-Recruitment}

\section{E-Recruitment merupakan} sebuah metode perekrutan para calon tenaga kerja baru dengan melewati beberapa tahapan yang ditentukan oleh sebuah organisasi dan menggunakan media komunikasi elektronik modern seperti internet untuk mendapatkan tenaga kerja yang layak secara efektif dan efesien (Irsan dkk, 2014).

\section{Unified Modelling Language (UML)}

UML merupakan suatu bahasa pemodelan visual dalam bentuk sketsa terhadap sistem perangkat lunak berorientasi objek berfungsi sebagai jembatan komunikasi beberapa aspek sistem (Nugroho, 2010 dan Padeli dkk, 2008). Teknik pemrograman berorientasi objek atau teknik pemrograman modern merupakan paradigma pemrograman yang menganggap segala sesuatu adalah objek (Utariani dan Herkules., 2017). 3 jenis UML yang digunakan dalam perancangan ini adalah :

a. Class Diagram : Memperlihatkan himpunan kelas-kelas, antarmuka, kolaborasi, dan relasi.

b. Use Case Diagram : Memperlihatkan himpunan usecase dan aktor-aktor.

c. Sequence Diagram : Diagram interaksi yang menekankan pada pengiriman pesan dalam suatu waktu tertentu.

5. Modeling Visual UML

Model

merupakan penyederhanaan realita yang mendeskripsikan sebuah sistem dari cara pandang tertentu. Alat bantu pemodelan visual membantu dalam hal menyembunyikan atau menampilkan hal-hal yang penting serta memelihara konsistensi selama permintaan kebutuhan, perancangan dan implementasi. Dengan adanya model maka memeprcepat dan mempermudah dalam mengambarkan sesuatu. 
Memberikan penjelasan lebih rinci tentang sesuatu. Serta Model bisa mewakili sesuatu yang nyata maupun yang tidak nyata (Padeli dkk., 2008).

UML memiliki konsep menganalogikan sistem seperti kehidupan nyata yang didominasi oleh obyek dan digambarkan dalam simbolsimbol yang cukup spesifik (Haviluddin, 2011).

UML salah satu alat bantu yang sangat handal dalam bidang pengembangan sistem yang berorientasi objek. Karena UML menyediakan bahasa pemodelan visual yang memungkinkan pengembang sistem untuk membuat cetak biru terhadap visi yang dimiliki. Sebagai sebuah sketsa, UML berfungsi menjembatani atau mengkomunikasikan beberapa aspek dari sistem. Berbagaimacam diagram UML dapat mengakomodasi berbagai sudut pandang dari suatu perangkat lunak yang akan dibangun. Diagram UML digunakan untuk :
a. Mengkomunikasikan ide
b. Melahirkan ide dan peluang baru
c. Menguji ide dan membuat prediksi
d. Memahami struktur dan relasi

\section{METODE}

1. Prosedur Penelitian

Prosedur yang dilakukan dalam pemecahan masalah penelitian rancang bangun sistem menggunakan metode System Development Life Cycle sebagaimana terlihat pada Gambar 1.

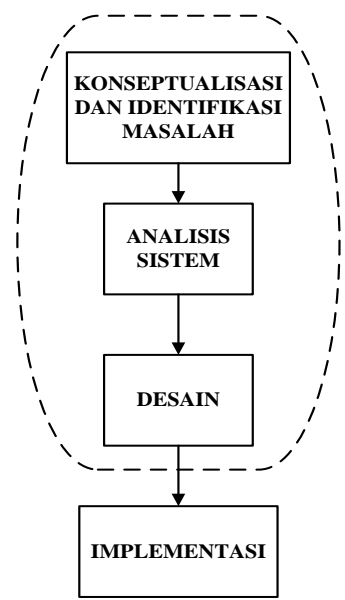

Gambar 1. Prosedur System

Development Life Cycle (Nugroho, 2010)

Gambar 1 memperlihatkan prosedur penelitian dengan 4 tahapan, dimana penelitian ini berada pada tahap konseptual dalam bentuk rancang bangun sistem. Tahap pertama identifiaksi masalah, pemahaman terhadap sistem yang sedang berjalan atau proses bisnis yang ada. Tahap kedua melakukan analisis, solusi yang ditawarkan berdasarkan permasalahan dan kebutuhan pengguna, tahapan ini digunakan untuk membuat keputusan. Apabila sistem saat ini mempunyai permasalahan, dan hasil nya digunakan 
sebagai dasar untuk perbaikan sistem.

Tahap ketiga membuat desain rancangan sistem berdasarkan solusi permasalahan dan kebutuhan pengguna, bertujuan untuk mendesain sistem baru yang mampu menyelesaikan masalahmasalah yang dihadapai dengan pemilihan alternatif sistem yang baik. Kegiatan yang dilakukan dalam tahapan perancangan ini meliputi perancangan input, file dan output. Tahap ke empat Implementation, dalam penelitian ini, merupakan tahapan lanjutan yang memiliki beberapa tujuan, yaitu melakukan kegiatan spesifikasi rancangan logika kedalam kegiatan yang sebenarnya dari sistem informasi yang akan dikembangkan, kemudian mengimplementasikan sistem baru kedalam salah satu bahasa pemograman yang sesuai. Sistem baru harus dapat berjala

2. Teknik Pengumpulan Data dan Analisis Metode Pengembangan Sistem

Adapun teknik-teknik yang digunakan dalam pengumpulan data adalah :

a. Teknik wawancara, dalam teknik ini dilakukan tanya jawab secara langsung, terhadap Kepala dan staff Bagian Admisi Universitas
Universal, mengenai sistem perekrutan pegawai. Jenis wawancara yang digunakan adalah wawancara tidak terrstruktur, dengan susunan pertanyaan dan susunan kata-kata dalam setiap pertanyaan dapat diubah pada saat wawancara.

b. Teknik pengumpulan data arsip (archival). Teknik ini membantu untuk melengkapi data-data yang dibutuhkan, seperti form penerimaan pegawai yang meliputi data diri pelamar, riwayat pendidikan, riwayat pengalaman dan bagian yang dilamar serta data yang terkait lainya.

\section{HASIL DAN PEMBAHASAN}

Rancang bangun aplikasi perekrutan pegawai berbasis WEB di Universitas Universal, dibuat rancangan sesuai dengan kebutuhan sistem, sehingga rancangan yang dibuat mampu mengusulkan untuk membangun suatu aplikasi perekrutan pegawai kedepan, agar memotivasi organisasi dalam peningkatan layanan (Nugroho dan sherly, 2017). Secara menyeluruh rancangan sistem digambarkan dalam sebuah kerangka sistem sebagaimana terlihat pada Gambar 2. 


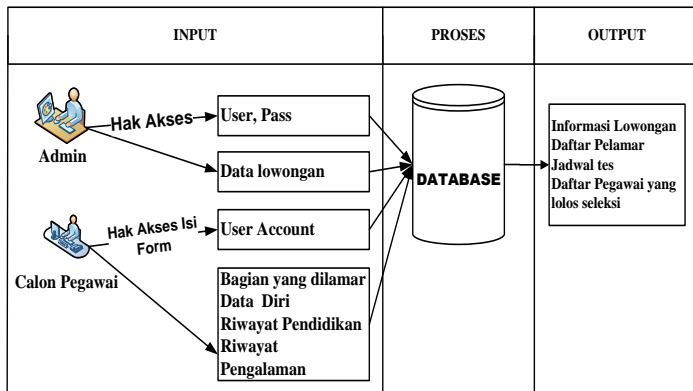

Gambar 2. Kerangka Sistem Perekrutan

Pegawai Berbasis WEB

Gambar 2 dapat dijelaskan bahwa untuk membangun rancangan sistem perekrutan pegawai berbasis WEB di Universitas Universal, ada dua pihak yang telibat dalam input data yaitu Admin yang mempunyai hak akses secara penuh terhadap sistem dan calon pegawai yang memiliki user account sebagai hak akses untuk pengisian data. Kemudian data diproses dalam basisdata dan telah dilakukan normalisasi. Sehingga sistem mampu memberikan output berupa informasi yang terkait mengenai perekrutan pegawai. Interaksi terhadap proses bisnis perekrutan pegawai sebagaimana yang terlihat pada Gambar 3.

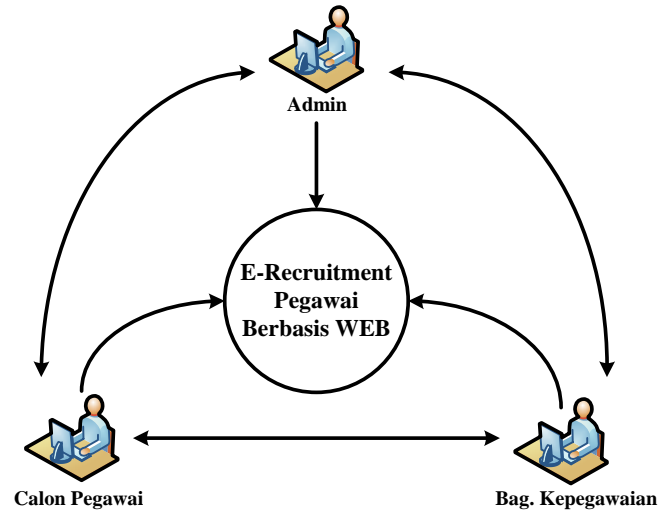

Gambar 3. Interaksi terhadap proses

bisnis perekrutan pegawai

Gambar 3 menunjukkan sistem sebagai perantara komunikasi antara 3 aktor yaitu calon pegawai, bagian kepegawaian dan admin sistem. Membangun sebuah sistem, khususnya sistem informasi perekrutan pegawai berbasis WEB, maka salah satu langkah awal yaitu membuat perancangan konseptual, dalam rancang bangun sistem menggunakan metode pemodelan berorientasi objek UML, untuk menjelaskan sistem yang akan dibangun atau dikembangkan. Pertama membuat gambaran use case diagram sebagai rangkaian sistem yang saling terkait secara teratur yang dilakukan atau diawasi oleh sebuah aktor sebagaimana yang terlihat pada Gambar 4. 


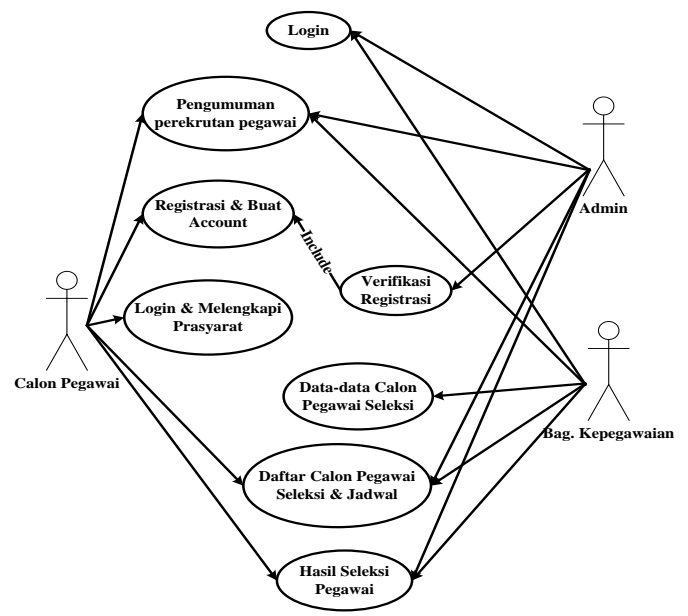

Gambar 4. Use Case Diagram

Perekrutan Pegawai Berbasis WEB

Gambar 4 proses untuk memberikan gambaran yang terjadi. Pada use case diagram, diketahui bahwa aktor yang terlibat pada proses tersebut adalah calon pegawai, admin, dan Bagian Kepegawaian. Admin melakukan tugas berdasarkan tugas dari bagian kepegawaian, admin melakukan login untuk hak akses dan memiliki beberapa hal yang bisa dilakukan diantaranya memasang pengumuman perekrutan pegawai, verifikasi data calon pegawai yang ingin melakukan lamaran atau melengkapi data dengan syarat harus memperoleh user account terlebih dahulu. Admin memasang daftar calon pegawai seleksi dan jadwal seleksi, kemudian admin memasukan hasil seleksi pegawai atau daftar calon pegawai yang diterima berdasarkan hasil akhir dari bagian kepegawaian.

Calon pegawai melihat pengumuman perekrutan pegawai, melakukan registrasi untuk mendapatkan user account, setelah mendapatkan user account calon pegawai melakukan login dan melengkapi data-data sebagai prasyarat melamar lowongan pekerjaan, kemudian calon pegawai melihat pengumuman calon pegawai yang diseleksi dan jadwal seleksi, setelah itu calon pegawai melihat pengumuman hasil seleksi pegawai. Bagian kepegawaian memiliki hak atas data-data calon pegawai seleksi yang telah mengisi data untuk melamar lowongan pekerjaan untuk ditindaklanjuti pada tahap seleksi sesuai kebutuhan dan mengunjungi halaman pengumuman perekrutan pegawai, halaman daftar calon peegawai seleksi dan jadwal serta halaman pengumuman hasil seleksi pegawai.

Class diagram terdiri dari beberapa tabel yang saling terhubung sebagai rancang bangun database sistem dengan metode pemodelan berorientasi objek UML sebagaimana terlihat pada Gambar 5. 


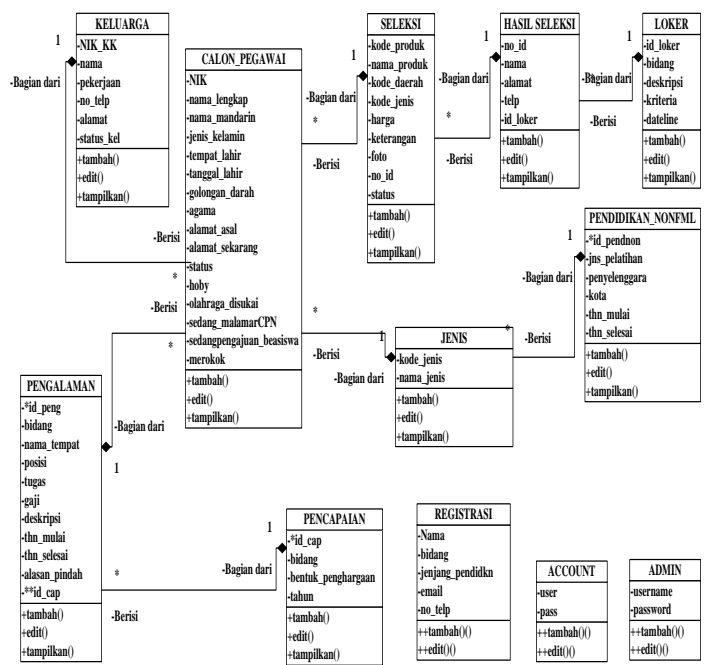

Gambar 5. Class Diagram Perekrutan

Pegawai Berbasis WEB

Kemudian menggambarkan sequence diagram calon pegawai untuk menampilkan interaksi-interaksi antar objek dalam sistem, termasuk pengguna, display, dan sebagainya berupa pesan atau penggambaran rangkaian langkah-langkah yang dilakukan sebagai sebuah respon dari suatu kejadian untuk menghasilkan output tertentu. Penggambaran sequence diagram calon pegawai dari sistem informasi Perekrutan Pegawai Berbasis WEB sebagaimana terlihat pada Gambar 6.

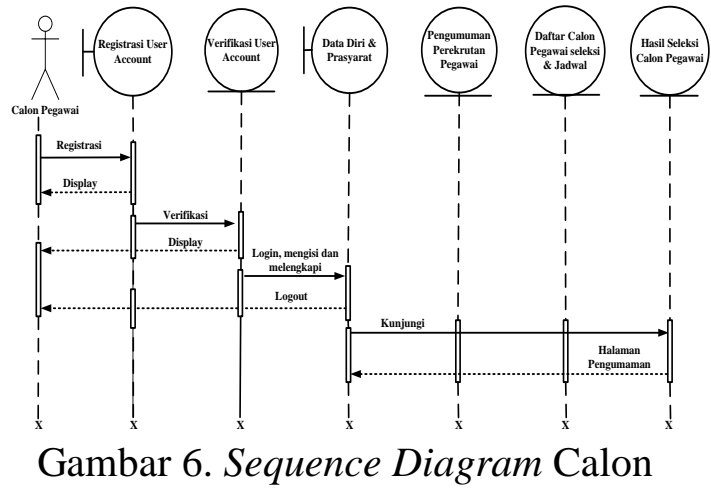

Pegawai

Gambar 6 aktor calon pegawai melakukan registrasi untuk mendapatkan user account agar dapat melengkapi data diri dan persyaratan yang diperlukan untuk melamar pekerjaan. Setelah mendapatkan verifikasi dari admin, maka calon pegawai mendapatkan user dan password. Calon pegawai dapat mengunjungi halaman pengumuman perekrutan pegwai, halaman daftar calon pegawai seleksi dan jadwal serta halaman pengumuman hasil seleksi pegawai. Berikutnya Sequence Diagram Admin sebagaimana yang terlihat pada Gambar 7. 


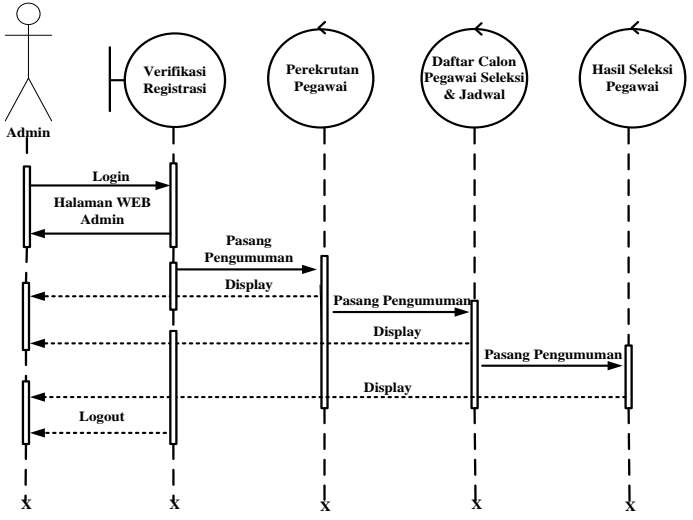

Gambar 7. Sequence Diagram Admin

\section{Gambar 7 Sequence Diagram}

Admin sebagai pengelola WEB perekrutan pegawai, admin melakukan login untuk verifikasi data calon pegawai yang ingin mendapatkan user account untuk melengkapi data diri dan prasyarat. Admin bertugas memasang pengumuman perekrutan pegawai, memasang daftar calon pegawai seleksi dan jadwal serta memasang informasi atau pengumuman hasil seleksi pegawai. Berikutnya Sequence Diagram Bagian Kepegawaian sebagaimana terlihat pada Gambar 8 .

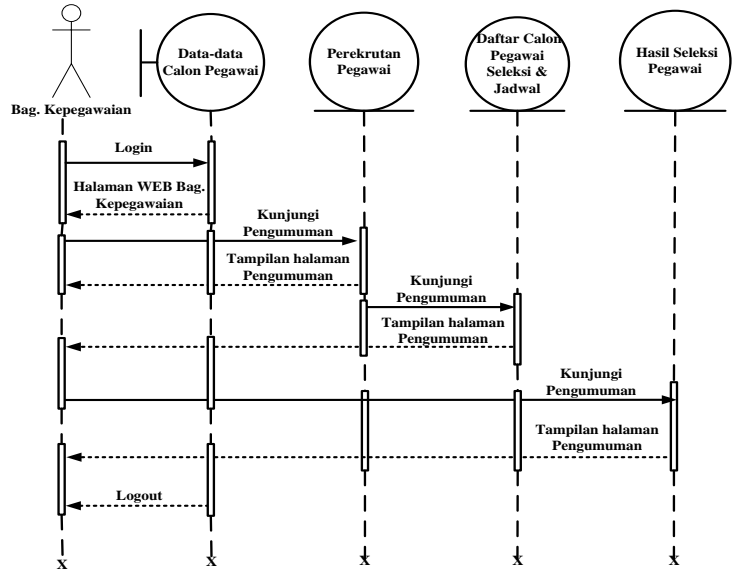

Gambar 8. Sequence Diagram Bagian

Kepegawaian

Gambar 8 menjelaskan bagian kepegawaian login untuk mendapatkan data-data calon pegawai yang telah melengkapi atau melamar lowongan pekerjaan. Kemudian bagian kepegawaian dapat mengunjungi halaman pengumuman perekrutan pegawai, halaman daftar calon pegawai seleksi dan jadwal serta halaman pengumuman hasil seleksi pegawai.

Rancangan antar muka sistem perekrutan pegawai berbasis WEB sebagaimana yang terlihat pada Gambar 9. 


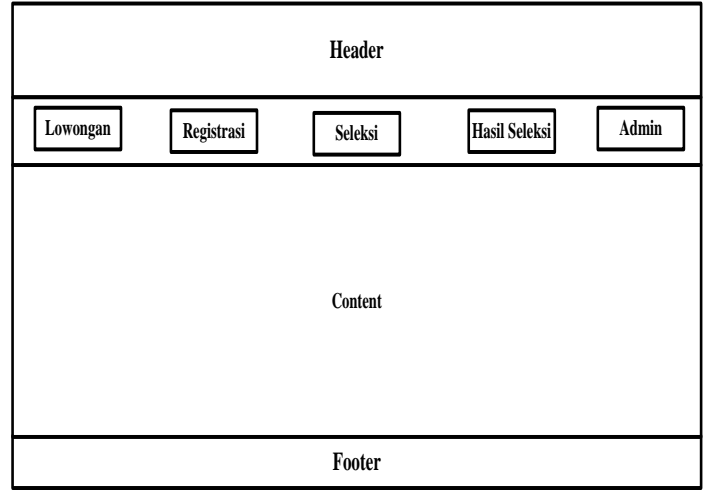

Gambar 9. Antar Muka Sistem

Perekrutan Pegawai Berbasis WEB

Gambar 9 rancangan antar muka sistem perekrutan pegawai berbasis WEB, yang terdiri dari lima fungsi command button yaitu lowongan, registrasi, seleksi, hasil seleksi dan admin. Lowongan berisi informasi lowongan yang terdiri dari attribute LOKER pada Class Diagram, informasi lowongan tersebut diisi oleh admin yang ditugaskan oleh bagian kepegawaian. Registrasi sama halnya dengan Admin yang memiliki tabel tersendiri, registrasi berisi attribute nama, bidang, jenjang_pendidikan, alamat_email, no_telp, sebagai data yang nantinya akan di verifikasi oleh admin, admin mengirimkan user account dan password sehingga calon pegawai mempunyai hak akses untuk melengkapi data diri dan prasyarat perekrutan pegawai, hal ini untuk membatasi kebebasan pengunjung untuk mengisi data yang sama. Seleksi merupakan halaman yang memberikan informasi mengenai daftar calon pegawai yang berhak mengikuti seleksi dan pengumuman jadwal seleksi. Kemudian halaman hasil seleksi, berisikan pengumuman hasil seleksi atau daftar calon pegawai yang diterima. Selanjutnya admin, berisi form input username dan password yang bisa digunakan oleh admin dan bagian kepegawaian untuk melihat atau memodifikasi dan mengambil data-data yang ada, guna tindak lanjut perekrutan pegawai.

\section{KESIMPULAN}

Rancang bangun aplikasi atau konseptual sistem, mulai identifikasi masalah, analisis kebutuhan sistem hingga design, penggambaran model pembangunan sistem menggunakan UML membantu untuk mempermudah dalam pembangunan sistem sesuai kebutuhan. Rancang bangun aplikasi memuat proses yang sesungguhnya dalam perekrutan pegawai di Universitas Universal.

\section{SARAN}

Adapun saran untuk mengoptimalkan proses bisnis perekrutan pegawai adalah membangun aplikasi WEB perekrutan pegawai yang terintegrasi dengan 
sistem Universitas yang ter-update

dalam bagian pengumuman salah satunya pengumuman perekrutan pegawai dilingkungan Universitas Universal. Kemudian menerapkan beberapa pola keamanan sistem yang handal pada aplikasi e-recruitment salah satunya untuk menghasilkan data calon pegwai yang akurat dan menjaga data calon pegawai dari pihak yang tidak berkepentingan.

\section{DAFTAR PUSTAKA}

Ayu, W., dan Perdana, I., 2014, Perancangan Sistem Informasi Rekrutmen Dan Seleksi Karyawan Berbasis WEB Di PT. Qwords Company International. Jurnal Manajemen Indonesia, 14 (3), 247-258.

Gat dan Kosasi, S. 2014. Pengembangan Aplikasi ERecruitment Dalam Perekrutan Karyawan. Eksplora Informatika. 3(2). 131-140.

Haviluddin., 2011, Memahami Penggunaan UML (Unified Modelling Language). Jurnal Informatika Mulawarman. 6 (1), 1-15.

Holm, A.B., 2010, The Effect of Erecruitment $O n$ the Recruitment Process: Evidence from Case Studies of Three Danish MNCs. Proceedings of the Third European Academic Workshop on electronic Human Resource Management. Bamberg, Germany.
157. 91-111.

Irsan, M., Yuliyasni, E., Nufus, K., Afrida, S., dan Ratnasari, E., 2014, Rancangan Aplikasi ERecruitment Pada PT. Kalila Indonesia. Seminar Nasional Teknologi Informasi dan Komunikasi 2014 (SENTIKA 2014) Yogyakarta, 429-435.

Nugroho, Adi., 2010, Analisis Dan Perancangan Sistem Informasi dengan Metodologi Berorientasi Object. Bandung : Informatika.

Nugroho, B.P dan sherly, J., 2017, Implementasi Sistem Informasi Berbasis Web (Studi Kasus Gereja Gke Sion Palangkaraya). Jurnal Saintekom. 7 (2). 138-152.

Padeli., Henderi., dan Suyatno., 2008, Membangun (E-Procurement) Pengadaan Barang dan Jasa Dengan Prinsip Good Corporate Governance dengan Visual UML. Journal CCIT, 2 (1), 69-79.

Ramaabaanu, R and M. Saranya., 2014, Importance and Problems of ERecruitment. International Journal of Research (IJR). 1(9). 445-450.

Sills, M., 2014, E-recruitment: A comparison with traditional recruitment and the influences of social media. Human Resource Management.1-55.

Sharma, N., 2014, Recruitment Strategies : A power of ERecruiting and Social Media. International Journal of Core Engineering and Management (IJCEM). 1 (5). 15-35. 
Utariani dan Herkules., 2017, Monitoring Bimbingan Skripsi Online pada Sekolah Tinggi Manajemen Informatika dan Komputer (STMIK) Palangka Raya. Jurnal Saintekom. 7(1). 3347. 